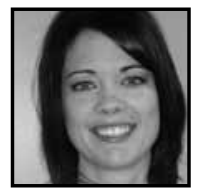

\title{
Old Pathways, New Directions: Using Lived Experiences to Rethink Classroom Management
}

\author{
Jamie Zepeda, University of Saskatchewan
}

\section{ABSTRACT}

Two stories lived and told become an entry point towards reflecting on issues of teacher practice related to classroom management. Using a narrative inquiry approach, personal experiences with Michael and Carlton-two kindergarten students-are pivotal in developing a deeper understanding of the difference between punitive and instructive discipline. Drawing on the philosophies of Vivian Paley, the reader is left with creative possibilities for new directions in attending to children's unmet needs and, at the same time, ideas for facilitating a supportive and inclusive classroom environment for all learners.

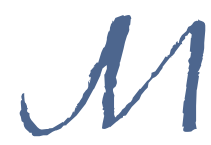

y journey as an elementary teacher has been much like a road trip with a group of great friends. The anticipation that arises before a longawaited get-away is similar to the feeling I have before a new school year begins, as I anxiously wait to meet the new group I will journey with that year. My friends, and my Kindergarten students, have provided me with valuable and insightful life lessons such as the value of patience and compassion. As the school year or a road trip comes to an end, I am comforted and humbled by the solidifying of friendships and bonds created. These life and professional lessons help me grow as a teacher so that I can better understand each child with whom I travel.

Much like the markings of a road map, my teaching career has taken many twists and turns and found a few rocky roads as I have stumbled in fully understanding and adapting to successfully meet the needs of each child. Most times I have arrived at my destination smoothly, without any major detours. This year, however, 
a new student has challenged me to stray far from the familiar pathways to which I have grown accustomed. I have begun to revisit past teaching experiences and question certain conceptualizations that I assumed to be absolute. As I have traveled with Michael, ${ }^{1}$ a young boy who has challenged every fibre in my body and belief in my mind, considerations about control, consequences, and unmet needs have started to cloud my thoughts, and the direction I was planning to take as a teacher has shifted.

Clandinin and Connelly (2000) wrote that "learning is change" and in order for individual growth to happen, we must look back and study our past experiences, or as they say, our "personal practical knowledge" (p. 7). While these personal experiences are not only meaningful and relevant to us as individuals, they help us to "interpret the worlds in which [we] live" (Eisner, as cited in Olson, 1995, p. 120). As I struggle to interpret the actions of Michael, my new student, I am forced to examine the actions I choose to take and the ones I have chosen in the past, particularly as I think back to another boy named Carlton who helped me to see the role I played in the daily behaviour issues we encountered. Pausing to revisit these experiences and to consider the detours and pit-stops I have made along the way, I develop new insights into the directions I may travel in the future.

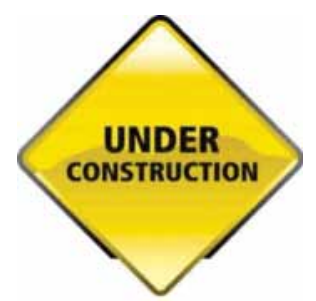

\section{Michael}

"In my opinion, he needs a consequence," she calmly states, trying hard not to let the dissatisfaction she's feeling erupt onto me, but the clenched fists and tight shoulders says it all. Her kind and caring manner is disguised momentarily by the increasing frustration we both are feeling towards one particular student.

Diane, our Educational Assistant, and I have been working together every afternoon for five months and one continuing topic of discussion is Michael, our most challenging student, with whom we sometimes struggle to agree on regarding appropriate methods of discipline. After reading The Boy on the Beach (2010), I found myself enamoured by Vivian Paley's careful attention to the needs and feelings of her 
students while also decoding the children's language and interactions in their play. This was what I hoped to achieve in my classroom using the storytelling and storyacting curriculum Paley modeled in her books (1981, 1984, 1990, 1992, 1995, 1997, 1999, 2004 , 2010). This quality time that I devoted for the students to sit with me and tell their own story as I record it has proven to be a valuable method to build intimate relationships between the storyteller, myself, and the audience. It is a "shared process" (Paley, 1990) in that the children contribute and confirm ideas being created, and later take part in the dramatization of their original stories. As the actors proudly take on their designated role chosen by the storyteller, a sense of unification envelops the class as they make personal connections together through another child's story.

Storytelling is one area in which Michael excels, making it look effortless in how he presents a character with his detailed expressions and sound effects. These stories give Michael a "new script to follow" (Paley, 2010, p. 23) in that he explores other ways to react and handle certain situations. Unfortunately, as we repeatedly see in the stories he dictates, he often chooses the role of "the scary monster" and, like any good actor, he fully accepts that role in class as he growls at the other children when they don't understand his ways and roars when he feels his needs aren't being met.

"There's a scary monster! Roarrrr!!! He's bad you know. He will eat you up!" Michael has captured my curiosity. "Why is he bad?" I ask.

"Cuz he's a bad monster. Bad, bad, bad. People are bad to him. And his eyes are red. Scary eyes."

Michael's first story paints a clear picture of the perceptions he has of himself. As we continue on our journey with storytelling, it has become apparent that the children see this time as a safe place to explore and experiment with different scenarios and try on new roles (Engel, as cited in Wright, Bacigalupa, Black, \& Burton, 2008). Michael continues on with the scary monster role as playtime ensues...

Michael has just returned from a body break and his attention is instantly drawn to the intricate castle his classmates are building on the carpet.

"Rooooaaaarrrrrrrr!" goes the loud and scary monster, charging at the elaborate castle. As each block comes tumbling down, Michael's eyes widen with pleasure until he hears the cries of his classmates as they watch their creation fall into rubble. 
After learning a little about his history and talking with him about his actions, I've come to realize that when Michael knocked over the castle his friends just built, he wasn't doing it to be malicious or mean-he was acting out his own story. Though his classmates were not aware of this, he was a giant, fire-breathing dragon coming to knock down the castle and rescue the princess. In his mind he was being a helpful friend-but his good deed only seemed to get him in trouble again.

With heavy hearts and a feeling of defeat, Michael and I rejoin the children at the carpet. Recess proved to be a challenge for him again and the supervising teacher was not happy. "Would you like to act out old stories today?" I ask the class as I peruse our abundant collection. "Remember my scary monster story? Can we do that one?" Michael shouts. That suggestion could not have been more fitting as it was only mere moments ago that he had resembled someone very similar outside. He created this story a month ago and it detailed the naughty things scary monster did at recess-a perfect correlation to his behaviour today.

"Why is he the scary monster again?" I ask, hoping for an answer the second time around.

"Cuz he's mean and yells at people and throws things at them!"

"Oh yes, I see. So, would you like to rewrite the ending this time Michael? Could the scary monster turn into a good monster?"

"Hmmm..." he thinks for a moment. "Yeah!" he excitedly shouts as do his classmates. It appears as though this idea has never presented itself before.

"Well how will he do that?" Michael thinks for a mere moment...

"He can help them outside and say nice things and open the door," he chimes in.

"You just have to say 'hocus pocus,' adds Jace.

"—and say 'nice monster!' shares Kelvin.

"And he magically turns into the nice monster?"

"Yup," replies Michael, "and he has friends."

With the help of the class, we often create a class story that targets a specific child or behaviour that I want to address. By role-playing and brainstorming other ways to react in certain situations and then creating a story about it, Michael has begun to see himself in a new role, sometimes the Superhero that saves the day and does kind things for others. His classmates have even taken it upon themselves to remind him, "Be the Superkid, Michael, like in the story," when he starts to act out. 
Unfortunately, this new role isn't always familiar to him, and the desire to cooperate and follow directions is a pathway he does not feel compelled to follow.

As we sing our goodbye song to end the day my eyes are focused on Michael, as are Diane's. Transitions have become a significant challenge for him and we are both sensing trouble looming ahead.

I put my arm around Michael as we sing but as the song comes to a close he breaks away and shouts, "Again! Again! Again!!" He runs to the table and creates a fortress with the chairs around him to keep himself enclosed. Lately we have been letting him stay there until he is ready to come out and talk, which he usually does in his own time. But today he decides to yell and scream and kick at the table and chairs. By this time several parents have arrived and are patiently waiting for their children, while also witnessing this explosion. Our creative pleas to try and get him out cannot be heard through the shouting so Diane picks him up and carries him off to the bean bag, a cozy chair that's just across the hall in a quieter space in the library.

The frustration and despair we feel in taking Michael to the bean bag chair does not sit well with me. This is our "last resort," and though we make it a point to be more creative in our ways of discipline, it seems to be the only place where Michael can regroup and start again. It was this latest incident that caused Diane and me to discuss "consequences" and how to effectively respond to Michael. Through my experiences with Michael, l've found that there is a rhyme to his reason-we just have to figure out what his rhymes and reasons are. At the same time, Diane is right in that the consequence of going to the bean bag chair works wonders in getting him to comply to our demands. Why is it, that, though I respect her opinion, my heart tells me that isolating him from the group is detrimental to his own self-worth and that of the class?

As I head down the street to my home, my thoughts linger back to Michael and I feel anxious about the journey ahead. It does not provide me with the feeling of comfort like the road signs which lead me on my drive home. On this pathway the road signs are foggy and blurred, leaving me with feelings of uncertainty, a sense that I might get lost. But when I think of Michael's hazel-colored eyes filled with wonder, hurt and confusion, images of another little boy that was once very much like Michael drift into my mind, and I remember the profound lessons I learned from a unique little boy whom I met during my first year of teaching. He taught me to not only seek to understand the behaviours of the students, but also the importance of reflecting on my own. 


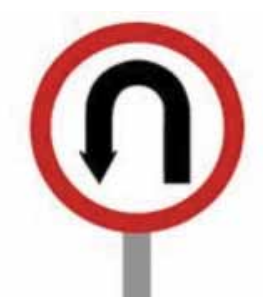

\section{Carlton}

Our school was situated just at the top of the hill in Northern Saskatchewan, surrounded by many picturesque character homes, some beautiful red brick homes with white pillars holding their ground, others with detailed features and a story to be told. On my walks to school I always revelled in the smell of the fresh flowers, and the lush greenery that covered the streets like an umbrella. But as the streets sloped downward and I began to descend, so did the beauty of the houses, the greenery, and my sense of hope. It was this area of town that Carlton called home.

"Look-it teacher!" shouted Carlton from across the tiny Kindergarten classroom we occupied. A small rectangular box would be the best way to describe it, with one shelf to put books on. But I made that classroom our own and filled it with fuzzy character puppets strung across the ceiling on a clothesline, a story corner made cozy with a white bear-skinned rug and a kid's-sized red, leather chair for me to sit on. That, along with 20 bustling, creative, Kindergarteners eager to learn something new made our classroom a fun, albeit sometimes cramped, place to be. Since space was limited in this room, you can imagine my dismay when I found that five-year-old Carlton, with his chocolate-pudding stained face and tousled brown hair had meticulously scattered marbles around the classroom. "Now when people step on 'em they'll slip and fall on their head! Hahaha," he roared.

"No Carlton," I said with a condescending tone. "Go pick up all those marbles right now - somebody will get hurt!" I was too irritated to sense the hurt and disappointment in his face but I felt it in my heart. With his head down and feet lagging, he sadly picked up his masterpiece and returned some of the marbles to their place. "There's more over here," I complained, cringing as I heard the annoyance in my voice. As I watched him clean up, I recalled the many other things he'd done that day to 'disrupt' our learning - or at least that's the way I saw it at that time. Mixing all the paint colors I had just cleaned and set out, scribbling over the table and his paper when he was supposed to be writing his name, and leaving his snowy, wet winter boots in the middle of the floor where I had just slipped on the puddle they had created, were just some of the incidents that had caused me to lose my patience with Carlton that day. 
I desperately wanted to help Carlton become successful in his endeavours at school, to have him be seen as an equal member of the class, and to have him accomplish the same tasks his classmates rejoiced in-but how? I had laid out my expectations for Carlton, I had been consistent with the consequences, but Carlton still seemed to beat to his own drum. At times he was defiant, other times he didn't understand what was being asked of him, but my desire for him to conform and follow all of our classroom rules was escalating. At that time, I believed that a "good" classroom teacher assumed the authoritarian position of the class and always had control over her students. Our classroom rules had been created together and in many ways these rules were non-negotiable. So, when our class would tiptoe down the hallway as quiet as little mice, that one little mouse who would run up to walk beside me, leaving his place in line and not following the directions I had given, would make me feel as though I had failed in some way. Especially so when I'd hear other more experienced teachers share their "tricks of the trade." Being extra strict for the first months of the school year was a common "tip" that I heard often and one teacher even shared with me that she didn't dare smile until at least November. Hence, I continued on, being extra strict with Carlton, never thinking how my stern attitude and quick ability to point out what he was doing wrong was affecting him or the other children in the class.

The crisp autumn air wafted into the classroom and mingled with the sweet smell of cinnamon as the children decorated their teddy bear cookies with Smarties, jujubes, and other yummy treats on this beautiful fall day. The children took great delight in adorning their teddies with cinnamon hearts for eyes, a raisin for a nose, and a rainbow colored smile. The class was buzzing with excitement until we heard it. An all-too-familiar tone of voice filled the air with gloom and our excitement quickly diminished. "Nooo Carlton!" whined sweet, little Aurora. Not knowing what he did to receive such a reaction, Carlton looked around searching the faces of his classmates for some clues. "Carlton took all the Smarties! Now there's none for us!" she wailed and the looks of judgement from his peers quickly scorned any sense of accomplishment Carlton had in his creation. He tried to make it better by returning the Smarties to the tray but it was too late. The smell of righteousness permeated the class and has resonated in my heart ever since. It wasn't so much what Aurora had said that bothered me, but the tone of her voice when she said it. It wasn't just that she was upset that he took all the Smarties, but that it was Carlton who had taken all the Smarties. That voice, that tone, that judgement, was my voice coming out of a little girl's mouth. It was in this moment that I realized I had passed my negative feelings, my need to control, my indifference to his behaviours, and my judgement of Carlton onto my students. 


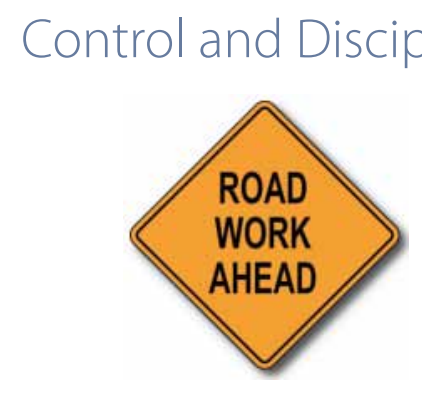

Where do these notions of control come from when managing a classroom? Paley (1984) mentioned that was a concern for her in that she didn't necessarily worry about control when working with the children, it was more "the appearance of control" (p. 77) for the outsiders looking in. This leads me to question who decides what "good" classroom management is? Can the rules be modified and changed to accommodate all children or is it a one-size-fits-all model? Always raising one's hand to talk, sitting criss-cross applesauce, marching quietly down the hall in a straight line, or organizing themselves in perfectly formed rows for story time have always held tensions for me as a teacher because they are rules created by the teacher which are mainly just teaching the children to conform. And then, for those students who disobey the teacher or classroom rules and expectations, how does a "good" teacher handle that? Do the children get a three-second countdown, a choice between two things - the favorable one being what the teacher wants, or the dreaded time out chair-where the disobeying child is isolated from the group and publicly embarrassed and labeled as "bad" in front of his peers? What happens when all of these common forms of discipline don't work? What special privileges must be taken away? Gym? Recess? Playtime? How much more can the teacher take away from a child before the child does what the teacher thinks s/he should be doing?

David Elkind (2001) wrote that his dictionary provided two main definitions for the word discipline: the first being "training that develops self control, character or orderliness, and efficiency" (p. 7), which he later labeled instructive discipline; the second being "treatment that corrects and punishes" (p. 7), which he called punitive discipline. The first approach teaches life skills and fosters an environment of teaching for children's understanding, encouraging students to intrinsically change behaviours. The second also teaches children to change behaviours but for extrinsic reasons, such as time away from the group or the loss of something of value to the child. One encourages a discussion and promotes awareness and reflection to the problem at hand, the other closes the door to new possibilities by narrowing the pool of problem solvers to that of just the teacher rather than the community. Instructive discipline is 
an informative style of discipline in that it provides children with guidance in understanding why they are engaging in certain behaviours and how they can better interact with their peers in their environment. Unlike its counterpart, instructive discipline creates dialogue (Paley, 1990), and gives the teacher and child an opportunity to discuss the problem in a non-threatening manner. It acknowledges that "children are in the process of learning acceptable behaviour" (Hemmeter, 2007, p.14) and that we as adults need to find creative ways to better understand their behaviours so that we can teach to them as we create our classroom curricula. Providing children with the necessary strategies to solve their own problems and be reflective of their actions empowers them and helps them to positively connect with others. The children also learn that their thoughts and feelings matter to the group, thus creating a sense of belonging.

Punitive discipline suggests that certain behaviour is unacceptable, therefore it needs to be "stamped-out" (Elkind, 2001). This style of discipline does not see children as competent and capable learners (Saskatchewan Ministry of Education, 2010), but rather imposes the philosophy that teacher knows best. Time-outs, the withdrawal of special activities, firm tones and words are often used to teach the child to stop the behaviour because s/he learns that if you do this, then you will lose thiswhether it be your recess, time spent with friends, or even the respect of your classmates. The dreaded time-out chair, which I later re-named the "thinking" chair, was later changed again to the "ready" chair, is based on the premise of punitive discipline. Whether it was time "out" of the group, time to "think" away from the group, or time to wait until you're "ready" to join the group, the concept was still the same; the child was excluded from the group in order to be taught a certain behavior. It occurred to me, as I immersed myself in Paley's work (1990), that it seemed to be the same kids in that chair day after day. She argued that time away from the group, whether it be a timeout or removal from an activity, "seldom helped a child not to do something, though it did notify everyone that the child was bad" (p. 88). In this way students often feel powerless in their ability to make the choices for themselves; they are almost being bullied into making what teachers see to be the correct choices.

Let me return to the earlier experience I had with Carlton and the marbles to make sense of my current experience. As I look back now, I see that his idea to scatter the marbles around the room could very well have been a "mistaken behaviour" (Villareale, 2009) in that the end result did not play out the way he had planned. Maybe he'd just seen someone slip and fall on TV and was trying to re-enact it. Replaying that moment, through the lens of instructive discipline and Paley's (2010) notion of giving children "a new script to follow" (p. 23), perhaps instead of admonishing him, I could 
have worked with him to create a story about the situation, discussing safety issues at the same time, or comparing how things we see on TV can play out differently in real life. In this way, the mistaken behaviour is not seen as a "mistake" but more of a "mis-take" or a "missed-take" (D. Pushor, personal communication, July 30, 2012) in that the child might require a "take two" or a "take three" to get to where both he and his classmates are content with how his actions unfold. Utilizing my time to understand Carlton's reasoning would have provided me with a productive way of addressing the situation, but it also would have taught him to think about how these "takes" will affect his classmates, in this case, their safety. By my "seeking first to understand" (Covey, 2008), Carlton is shown that his ideas have value, while also teaching his classmates to see the value in his contributions.

What I have come to understand is that I, as a teacher, have such responsibility to be conscious of how my responses and reactions can affect positive or negative change in the classroom. While I am constantly seeking to be a positive example for my students to follow, sometimes I am unconsciously led astray by a student's challenging behaviour. What I learned from Carlton is that perhaps it's not just the child's defiant attitude that's causing such a tumultuous eruption-but, as in my case, the teacher's lack of understanding or effort to make sense of the issues the child is facing. I have learned that stopping to examine my own behaviours and reactions to the mounting frustrations I may be facing consistently proves to be beneficial for both myself and the child I wish to assist and support.

\section{The Needs We Seek to Meet}

Children are unique in the talents and skills they possess and, in the same way, their needs are just as diverse. Cooper (2009) believed that when children act out it is because they have unmet needs and Gersten (2011) added that these "behaviours are strategies [they] use to draw attention to [their] needs" (p. 71). Often times the children we work with are not developmentally mature enough to communicate their needs and feelings in a way that we see as appropriate. Their past experiences have helped to shape how they handle certain situations. By acting out, they are asking for help to learn ways to have their needs met. When Michael hit another child because she took the dinosaur he was playing with, he had a need to get his dinosaur back but no strategy to do so that wouldn't hurt someone else. Rather than sending Michael off to the time out chair for being "hands-on," what if I use this incident as a teaching opportunity? I want to work with Michael in such a way that I help him to 
understand what he was feeling when he hit her, how else he could act on that feeling and why learning and practicing different ways to handle the situation next time would be far more valuable for Michael and his classmate.

Cindylee Villareale (2009) wrote that "mistakes do not need to be condemned or punished; they need to be used as teaching opportunities" (p. 77). By taking the time and patience to attend with Michael to the complexity of his actions, I am able to help him position himself to problem solve differently the next time a similar situation presents itself. By providing him with this opportunity to relive the experience and try again, he sees that his actions hurt someone, but he is not made to feel like an outcast for requiring another "take." His classmates are eager to help re-create the script and begin to see the "mis-take" simply as "awkward stage business that need[s] reworking" (Paley, 1990, p. 90).

The experience with Carlton has stuck with me for years because I felt that although I had good intentions, I knew deep down in my heart that I was hurting him with my ignorance more than I was helping him. My desire for him to just "be good like the rest of the kids" was unrealistic when taking into consideration his life experiences and his five year old "personal practical knowledge" (Clandinin \& Connelly, 2000). Carlton truly didn't have any other strategies to address his unmet needs and, more than anything, he just wanted to fit in and be loved. He wanted to feel a sense of belonging, that he too was a valued member of the class. Being constantly reprimanded by me for the majority of his actions was not helpful. I was too busy to notice any of the good things he did because I was so fixated on what he was doing wrong, or as I now see it, his "mis-takes." If this was the example I was setting for my class, what was I teaching them in regards to dealing with children or people that we see as different from ourselves? I was preaching about kindness and compassion while at the same time acting another way when I was responding to Carlton.

After the Teddy Bear Picnic, I began to see both myself and Carlton in another light. It became clear to me the role I had played in how the children came to understand and interpret the actions of one another. My behaviour also had to be accounted for and had its ramifications. Wearing my instructive lens and determined to create a new script with Carlton, we celebrated that he colored on the paper (instead of the table), or that he brought his boots into the classroom (instead of leaving them in the front entrance). We also began to notice the kindness he had for his classmates and his eagerness to be accepted and welcomed into the group. The class became more at ease because I was more at ease, and though Carlton still had those moments, we used them as opportunities to educate both him and the class in a more 
authentic way. By the end of the year, it became obvious that Carlton had proved to himself and the rest of the group that he was a valued member of the class. With our expression of our belief in him, he became necessary to the group and developed a sense of belonging (Paley, 2010).

Now it would be just too easy if I told you things were the same with Michael. Though he has made great strides in learning how to play with others cooperatively, showing kindness and compassion to his peers, and participating with the group, we still struggle in understanding how to meet his needs in some situations. I believe that one of Michael's unmet needs is that of control, and if he feels like he doesn't have any control in any one situation, he retaliates. To help meet this need, I am creating a classroom environment in which Michael has some freedom in what he chooses to do, whether it be leaving the group to do a puzzle or going for a body break, when he is feeling challenged or frustrated. Together with his help and ideas, we have created a book that we read daily which helps him to remember other options available to him when he is feeling stressed. Perhaps more importantly, I have had to relinquish some of the control I thought I needed as teacher.

"What can we do to help solve this problem, Michael? We seem to have run into it several times today." He has decided not to clean up after playtime which followed into a refusal to go for recess and another rejection to participate in gym.

"I don't know," he stubbornly replies. He has buried his head in his arms and we are both feeling the fury of frustration as we are lacking the ability to understand each other.

"We all want you to be happy Michael, and it doesn't look to me like you are happy right now. What can we do to help you?

"I DON'T KNOW!!" he honestly and angrily shouts. We replay a variety of strategies we have used in the past but not one will suffice. I finally pull out a piece of paper and have him draw me a picture and I am intrigued to see what he draws. To the untrained eye it might resemble nothing more than scribbles on a page, but I can see from his pursed lips and intent stare that he has created something that resembles a zigzags pattern. "I can do zigzags" he sweetly suggests.

Through a thoughtful and reciprocal conversation, we conclude that when he feels angry or needs a break he can walk in zigzags around the room. Though it seems like an odd strategy to employ, strangely, it worked itself in as one of his options 
to choose from when he was feeling explosive. He took ownership and responsibility for his behaviour and, with some guidance, he found what worked for him. The zigzags were posted on the wall for his classmates to share in support of his solution.

Michael and I continually reflect on the strategies we are using and we change or modify them when needed. By including him in the decision-making process, he feels empowered and confident in making choices that affect him and others in a way that is acceptable to everyone. By retelling and reliving (Clandinin \& Connelly, 2000) those moments daily, our energies are focused on the prevention of the "mis-takes" and not always on dealing with the after-effects of them. In this way Michael knows that his thoughts and feelings matter to the group and together we can work out the problem in a positive way.

As conscious as I try to be in seeking to find the creative answer to the problem at hand, other circumstances sometimes cloud my abilities to perform at the level I wish to. I still consider myself at the beginning of my journey as I travel from a punitive style of discipline towards an instructive method. I am confident there will be many more insightful practices I will encounter, however, it brings me comfort to see that on those days when I stumble onto those rocky roads, my class now steps up and takes the wheel.

It had been a challenging day for Michael and my patience had reached its limit. "I think you need to spend some time in the bean bag for a bit until you're ready to calm down Michael. Come back when you're ready," I say, feeling defeated.

Sensing our mutual frustration, the children are quick to remind me of our class values and beliefs. Almost bouncing off the floor, Miranda shouts sympathetically, "I'll go with him!"

"Me too!" the others chime in, standing up in his support.

"That's so sweet of you. Why do you all want to join Michael?" I ask.

"So he won't be lonely," remarks Joey. A sheepish grin spread across Michael's face from ear to ear as he looked around and felt the love and support from his classmates. He belonged. 


\section{Concluding Thoughts}

That first year with Carlton and the shame I felt at that moment when I heard Aurora's voice echo my own has been a constant reminder to me throughout my teaching career-most especially when I work with those students who are more challenging than others, students such as Michael. I have come to understand that every student comes to my class with a different and unique background and upbringing - a story. Carlton was no exception. Though I can't change what has happened in the past, I can change how I react in the present, and those reactions can help me to mold and change my future pedagogy and practices in a positive way. My experiences with both Carlton and Michael are tough to relive, to write down, and share with others, because they are not all moments I am proud of. But they are experiences that I needed to have to help me understand why I believe so strongly in what I do. Without these reflections on those lived experiences, I most likely would have continued repeating those same mis-takes, traveling down that same path, always putting the blame on the children, believing it was their fault and choice for acting out in the way that they do, rarely looking at the role that I played in the situation. Carlton's story has helped me to see just how essential it is for me as a teacher to make that extra effort to really understand my own personal and practical experiences and that of my students. It is this particular experience that encourages me to continue on my journey, seeking to find caring and instructive ways to work with Michael. My hope is not to head down that same path again, but to create a new one.

\section{Note}

1. Pseudonyms have been used to protect the anonymity and confidentiality of all individuals in the narratives.

\section{References}

Clandinin, D. J., \& Connelly, F. M. (2000). Narrative inquiry: Experience and story in qualitative research. San Francisco: Jossey-Bass Publishers.
Cooper, P. M. (2009). The classrooms all young children need: Lessons in teaching from Vivian Paley. Chicago: University of Chicago Press. 
Covey, S. R. (2008). The leader in me: how schools and parents around the world are inspiring greatness, one child at a time. New York: Free Press.

Elkind, D. (2001, Sep. - Oct.). Instructive discipline is built on understanding. Child Care Information Exchange, 1, 7-8.

Gersten, M. (2011, Jan. - Feb.). Addressing children's challenging behavior: Teaching with respect. Child Care Exchange, 1, 70-73.

Hemmeter, M. L. (2007, Jul. - Aug.). We are all in this together: Supporting children's social emotional development and addressing challenging behavior. Exchange: The Early Leaders' Magazine, 1, 12-16.

Olson, M. (1995). Conceptualizing narrative authority: Implications for teacher education. Teaching and Teacher Education, 11(2), 119-135.

Paley, V. G. (1981). Wally's stories. Cambridge, MA: Harvard University Press.

Paley, V. G. (1984). Boys \& girls: superheroes in the doll corner. Chicago: University of Chicago Press.

Paley, V. G. (1990). The boy who would be a helicopter. Cambridge, MA: Harvard University Press.
Paley, V. G. (1992). You can't say you can't play. Cambridge, MA: Harvard University Press.

Paley, V. G. (1995). Kwanzaa and me: a teacher's story. Cambridge, MA: Harvard University Press.

Paley, V. G. (1997). The girl with the brown crayon. Cambridge, MA: Harvard University Press.

Paley, V. G. (1999). The kindness of children. Cambridge, MA: Harvard University Press.

Paley, V. G. (2004). A child's work: the importance of fantasy play. Chicago: University of Chicago Press.

Paley, V. G. (2010). The boy on the beach: Building community through play. Chicago: University of Chicago Press.

Saskatchewan Ministry of Education. (2010). Kindergarten. Regina, SK: Curriculum and E Learning.

Villareale, C. (2009). Learning from the children: Reflecting on teaching. St. Paul, MN: Redleaf Press.

Wright, C., Bacigalupa, C., Black, T., \& Burton, M. (2008). Windows into children's thinking: a guide to storytelling and dramatization. Early Childhood Education Journal, 35, 363-369.

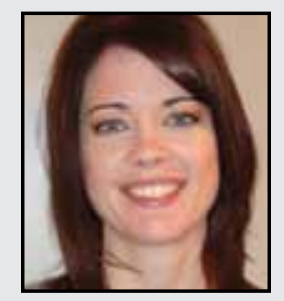

Jamie Zepeda recently completed a Master's degree in Early Childhood Education at the University of Saskatchewan. Her research, an autobiographical narrative inquiry, focuses on the philosophies of Vivian Paley in using a storytelling curriculum to enhance classroom community and relationships between the teacher and students. Jamie has taught in various elementary school settings. Her passion resides with her two little girls and the kindergarten children she teaches and is inspired by. 